Mariola Tracz

Uniwersytet Pedagogiczny, Kraków, Polska

\title{
Rola edukacji w budowaniu kapitału społecznego w Polsce
}

\section{The Role of Education in Building Social Capital in Poland}

Streszczenie: W niniejszym opracowaniu ukazano elementy teorii kapitału społecznego w odniesieniu do rozwoju społecznego i gospodarczego oraz roli edukacji w jego budowaniu.

W pierwszej części przedstawiono koncepcje podejścia do kapitału społecznego, typów kapitału i jego oddziaływania na rozwój gospodarczy. W drugiej części podjęto próbę określenia roli edukacji w rozwoju kapitału społecznego. Przedstawiono relacje pomiędzy edukacją a kapitałem społecznym na przykładzie zachodzących przemian strukturalnych i programowych w oświacie w ostatniej dekadzie w Polsce. Ponadto zwrócono uwagę na ujemne zjawiska zachodzące w edukacji, które mogą stanowić istotne ograniczenia w wypełnianiu przez szkoły zadań w budowaniu kapitału społecznego.

\begin{abstract}
The paper present the aspects of theory of human capital in social and economic developed and the role of education in building this phenomenon. The first part of the article organizes actual knowledge on social capital and typology of this phenomenon and their influence on the economic development. The second part of the paper is devoted to identifying the relationship between the education policy and developed social capital. The relationship between the functioning education and the social capital is analyzed on the basis of the structural and curriculum changes in the educational system in last decade in Poland are presented. What is more, the article highlights negative phenomena occurring in the educational system, which might constitute a substantial obstacle in fulfilling the school's tasks to build the social capital.
\end{abstract}

Słowa kluczowe: edukacja; kapitał ludzki; kapitał społeczny; społeczeństwo informacyjne

Key words: education; human capital; informational community; social capital

\section{WPROWADZENIE}

Podjęta problematyka wydaje się istotna z tego względu, iż kształcenie ogólne i zawodowe to ważne obszary zainteresowań nie tylko pedagogiki, ale także socjologii i ekonomii. W kształtowaniu się gospodarki globalnej obserwujemy szereg procesów zachodzących w sferze ekonomicznej, społecznej i kulturowej, które oprócz korzyści przynoszą szereg 
negatywnych konsekwencji. Jednym z istotnych problemów społeczno-gospodarczych jest funkcjonowanie edukacji w kontekście podnoszenia jakości zasobów intelektualnych społeczeństwa, a także budowania kapitału społecznego.

Wielu pedagogów wskazuje na narastające problemy w funkcjonowaniu systemu oświatowego w warunkach neoliberalizmu, realizowanych programach kształcenia, w tym także szkolnych programach wychowawczych, które nie sprzyjają budowaniu współpracy, kreatywności i wymianie wiedzy wśród uczniów, a w konsekwencji podnoszeniu poziomu relacji społecznych.

Niniejsze rozważania są głosem w toczącej się dyskusji na temat edukacji, roli wiedzy i umiejętności w tworzeniu społeczeństwa informacyjnego i oczekiwań w tym zakresie zgłaszanych przez neoliberalną gospodarkę (a raczej rynek) wobec edukacji - systemu i szkoły jako zespołu osób i grup. Metodologiczną podstawą do podjęcia tych rozważań była krytyczna analiza materiałów odnoszących się do sfery edukacji - idei kształcenia, koncepcji horyzontu wiedzy, poziomu wykształcenia i kompetencji.

W opracowaniu odniesiono się do zagadnienia kapitału społecznego, koncentrując się przede wszystkim na procesie jego kształtowania w ramach kształcenia ogólnego i zawodowego realizowanego w polskim systemie edukacji.

\section{KAPITAŁ SPOŁECZNY - DEFINIOWANIE}

Zainteresowanie problematyką kapitału społecznego zaczęło się od zwrócenia uwagi na rolę wspólnoty społecznej w rozwoju gospodarczym, która wcześniej była zaniedbywana w rozważaniach teoretycznych. Pojęcie to do nauk społecznych zostało wprowadzone przez L.J. Hanifan w 1916 r. W swojej pracy zwróciła uwagę na to, że sąsiedzka współpraca na obszarach wiejskich dzięki zmniejszeniu kosztów ułatwia wytwarzanie dóbr i uzyskanie przychodu. Podobną zależność, ale w innych kontekstach zaobserwowano w ośrodkach miejskich (Sierocińska, 2011).

Termin „kapitał społeczny” został rozpowszechniony w latach 80 . XX w. przez socjologa J. Colemana, politologa R. Putnama oraz P. Bourdieu i F. Fukuyamę. Ogromne zainteresowanie tą problematyką wpłynęło na powstanie kilku definicji tego pojęcia, które jest odmiennie interpretowane przez reprezentantów różnych nauk (psychologów, politologów, socjologów, ekonomistów). Dokonując przeglądu definicji formułowanych przez różnych badaczy tego zagadnienia, możemy wskazać trzy klasyczne ujęcia tego terminu (Węziak-Białowolska, 2010):

- funkcjonalne, odnoszące się do cech organizacji społecznych, takich jak sieci (układy) jednostek lub gospodarstw domowych oraz powiązanych z nimi norm i wartości, które kreują efekty zewnętrzne dla całej wspólnoty (Coleman, 1990);

- paradygmatu działania zbiorowego, odnoszące się do przejawów samoorganizowania się ludzi i zaangażowania obywatelskiego opartego na zaufaniu społecznym i wspólnych wartościach (Putnam, 1995); 
- strukturalne, odnoszące się do zbioru rzeczywistych i potencjalnych zasobów, jakie związane są z posiadaniem trwałej sieci mniej lub bardziej zinstytucjonalizowanych związków opartych na wzajemnej znajomości i uznaniu, która dostarcza każdemu ze swych członków wsparcia w postaci kapitału posiadanego przez kolektyw i wiarygodności (Bourdieu,1989).

Inni autorzy odwołują się do ujęć, koncentrujących się na:

- jednostce: nacisk kładzie się na więzi (powiązaniu i zaufaniu) jednostek i członkostwo w sieci. Kapitał społeczny jest rezultatem inwestycji jednostek oraz zasobów posiadanych przez członków sieci (Coleman, 1990; Bourdieu, 1989);

- zbiorowości: wspólne działania grup i jednostek oraz kulturalne i organizacyjne społeczeństw (Putnam, 1995; Fukuyama, 2003).

W ujęciu socjologicznym w definicji kapitału społecznego nacisk kładzie się na normy oraz ich wpływ na spójność społeczną. W tym rozumieniu kapitał społeczny występuje w formie wartości, sieci i połączeń. W naukach ekonomicznych natomiast termin ten związany jest z pojęciami instytucji i ekonomii instytucjonalnej i obok cech zaufania i współpracy obejmuje także bardziej sformalizowane powiązania instytucjonalne (formalne i nieformalne).

Na podstawie dokonanego przeglądu literatury naukowej można zatem wnioskować, że kapitał społeczny odnosi się do takich cech, jak: zaufanie społeczne, zdolność do współpracy, wartości i normy postępowania, sieć kontaktów i poczucie wspólnoty, solidarność, zorientowanie na przyszłość, które mogą znacząco wpływać na wzrost aktywności społecznej i ekonomicznej ludzi.

Na potrzeby niniejszego opracowania przyjęto definicję kapitału społecznego zawartą w strategii Polska 2030 - trzecia fala nowoczesności (rozdz. VIII). Kapitał społeczny zdefiniowano tam jako potencjał zgromadzony w społeczeństwach i jednostkach w postaci instytucji, norm, wartości, zachowań stanowiących podstawę do budowania opartych na zaufaniu relacji społecznych, które sprzyjają kreatywności i wymianie wiedzy, przyczyniając się do osiągania celów, których poszczególne osoby nie byłyby w stanie zrealizować samodzielnie.

$\mathrm{Z}$ różnych podejść do koncepcji kapitału społecznego wynika podejście do:

- sposobu mierzenia kapitału społecznego: normatywny i absolutny;

- źródeł kapitału społecznego i jego aspektów;

- możliwości świadomego i planowanego rozwoju kapitału społecznego w danej społeczności (Juszczyk, 2007).

Należy także zauważyć, iż niektórzy badacze są przeciwni używaniu terminu „kapitał społeczny”, szczególnie słowa „kapitał”, gdyż nie odnosi się ono do rozumienia tego określenia w ujęciu ekonomicznym (akumulować, odtwarzać, produkować itp.). Wskazują, że kapitał społeczny to wartości niematerialne, które powstają w wyniku współpracy/ relacji między osobami (grupami), ich wzajemnego zaufania, zrozumienia, współpracy. 


\section{KaPITAŁ SPOŁECZNY A ROZWÓJ}

Część osób zajmujących się kapitałem społecznym uznaje, iż posiada on cechy kapitału w ujęciu ekonomicznym. Badania K. Kastro (2005) nad powiązaniami kapitału społecznego z cechami kapitału w rozumieniu ekonomicznym (rzeczowym) wykazały, że kapitał społeczny określa realny zasób, który ma znaczenie społeczne i posiada go każda społeczność w makro-, mezo- lub mikroskali. Kapitał społeczny może tworzyć (stanowić, wyzwalać) liczne sytuacje sprzyjające powstaniu dóbr i usług. Można zatem stwierdzić, że jedną z jego funkcji będzie podnoszenie korzyści zarówno w strefie społecznej, jak i gospodarczej. Niektórzy twierdzą wręcz, że kapitał społeczny jest istotnym fundamentem rozwoju gospodarczego.

Powszechnie uważa się, że niski kapitał społeczny oznacza małą liczbę więzi istniejących między ludźmi (mało osób zna się nawzajem) albo ludzie znają siebie nawzajem, ale nie obdarzają zaufaniem. Konsekwencją tego jest m.in. niepodejmowanie wspólnych lub indywidualnych działań, mających na celu poprawę życia ogółu społeczeństwa. Może się to przekładać na sferę gospodarczą, np. państwo musi odgrywać większą rolę w tworzeniu przedsięwzięć gospodarczych na dużą skalę (tzw. koszty transakcji). A w sferze społecznej niski kapitał społeczny lub jego brak powoduje powstanie dysfunkcji społecznych - korupcji, terroryzmu itd. (Fukuyama, 2003). Wysoki poziom kapitału społecznego występuje, gdy ludzie zawierają relacje z innymi jednostkami społeczności, obdarzają się zaufaniem i wspólnie lub indywidualnie działają z myślą o poprawieniu warunków życia. Rezultatem tego jest podejmowanie działań wspólnych i indywidualnych, np. w tworzeniu przedsiębiorstw, większej liczbie organizacji o charakterze pomocowym i charytatywnym, a tym samym koszty zawieranych transakcji są niższe. W innych dziedzinach życia wysoki poziom kapitału społecznego łączy się także z funkcjonowaniem ,zdrowego” państwa obywatelskiego oraz tworzeniem grup i stowarzyszeń będących wypełnieniem pomiędzy państwem a rodziną (Fukuyama, 2003).

W zależności od rodzaju więzi panujących w grupie wyróżniono kilka typów kapitału społecznego (tab.1).

Tab. 1. Typy kapitału społecznego według wybranych badaczy

\begin{tabular}{|l|l|l|c|}
\hline \multicolumn{1}{|c|}{ Robert Putnam } & Michael Woolcock & Jarosław Działek & Francis Fukuyama \\
\hline $\begin{array}{l}\text { Kapitał społeczny inklu- } \\
\text { zyjny (spajający) }\end{array}$ & $\begin{array}{l}\text { Kapitał społeczny } \\
\text { więzi }\end{array}$ & $\begin{array}{l}\text { Kapitał społeczny } \\
\text { zamykający }\end{array}$ & Kultury rodzinne \\
\hline $\begin{array}{l}\text { Kapitał społeczny eksklu- } \\
\text { zywny (łączący) }\end{array}$ & $\begin{array}{l}\text { Kapitał społeczny } \\
\text { mostów }\end{array}$ & $\begin{array}{l}\text { Kapitał społeczny } \\
\text { otwierający }\end{array}$ & - \\
\hline- & $\begin{array}{l}\text { Kapitał społeczny } \\
\text { powiązań }\end{array}$ & - & - \\
\hline
\end{tabular}

Źródło: opracowano na podstawie Sierocińska, 2011; Węziak-Białowolska, 2010

Z dotychczasowych badań nad kapitałem społecznym wynika, iż zależnie od rodzaju więzi, jakie dominują w społeczności, kapitał społeczny hamuje albo przyspiesza rozwój społeczny i gospodarczy. Wielu badaczy jest zdania, że kapitał społeczny typu inkluzyjnego 
hamuje rozwój społeczny, gdyż więzi skierowane są do wewnątrz, a to służy wzmacnianiu wartości i idei ważnych dla małych grup społecznych (homogenicznych), ale równocześnie następuje zamykanie się na konkurencyjne wizje ładu kulturowego, postęp i nowoczesność. Ustala się porządek chroniący status quo (Kwiatkowski, 2005; Sierocińska, 2011). Kapitał społeczny typu ekskluzywnego przyspiesza natomiast rozwój, gdyż więzi są skierowane na zewnątrz, łączą ludzi z różnych zinstytucjonalizowanych struktur i pomimo różnic w wyznawanych wartościach mogą wpływać pozytywnie na zmiany i innowacje grupy. Oba typy więzi nie wykluczają się, a relacje w wielu grupach społecznych mogą być jednocześnie inkluzyjne i ekskluzywne (za Putnam, 2008; za Sierocińska, 2011). Również oba typy kapitału społecznego mogą mieć charakter wzajemnie antagonistyczny, co zaobserwowano na przykładzie krajów Ameryki Południowej i części krajów tzw. Trzeciego Świata (Fykuyama, 2003).

Podczas prowadzonych w Polsce badań zaobserwowano przykłady niedostatku kapitału społecznego w szkole (Dudzikowa, 2008) i w społeczeństwie (Czapiński, Panek, 2011). Przyczyny tego stanu wynikają m.in. z przeszłości historycznej i ukształtowanych postaw, z niedostatku infrastruktury społecznej oraz niewystarczających działań w celu poprawy kultury organizacyjnej w sferze gospodarczej i publicznej.

\section{ROLA EDUKACJI W PROCESIE BUDOWANIA KAPITAŁU SPOŁECZNEGO}

Kapitał społeczny powstaje, gdy stosunki międzyludzkie ulegają zmianie w sposób ułatwiający współpracę. Proces ten odbywa się w wielu obszarach życia codziennego jednostki i grup społecznych w ramach zachodzących interakcji. W literaturze przedmiotu wyróżniono następujące obszary kształtowania się kapitału społecznego:

- rodzina,

- szkoła,

- praca,

- otoczenie i przestrzeń społeczna (Polska 2030..., 2012).

Powszechnie wskazuje się, że edukacja jest jednym z istotnych czynników wzrostu kapitału ludzkiego i społecznego (Borowiec i in., 2011; Kamińska, Hofer, 2012; Zioło, 2009).

Proces kształcenia w szkołach różnego typu sprzyja nabywaniu wiedzy, kształtowaniu umiejętności i kompetencji oraz systemu wartości i postaw niezbędnych w życiu zawodowym i relacjach społecznych młodego człowieka. To zobowiązuje pedagogów, nauczycieli oraz instytucje oświatowe do zajmowania się tą problematyką przez opis i charakteryzowanie zjawisk oraz informowanie opinii publicznej o przejawach nieprawidłowości zachodzących w tym procesie. Ujęcie pomiarowe otwiera z kolei drogę do analiz wzajemnych relacji kapitałów ludzkiego i społecznego oraz ich zależności od kontekstów, w jakich są wytwarzane, zwłaszcza w odniesieniu do programów edukacyjnych (Niemierko, 2011; Dudzikowa, 2008; Wiktorzak, 2009; Woolcock, 1998).

Istnieją zatem przesłanki, żeby stwierdzić, iż polityka edukacyjna państwa i jej realizacja w regionach (województwach, powiatach, gminach) ma istotny wpływ na poziom rozwoju 
kapitału ludzkiego i społecznego. W ostatnich 20 latach zmiany, jakie nastąpiły w systemie edukacyjnym w Polsce obejmującym szkolnictwo różnego poziomu (od podstawowego do wyższego), unaoczniają działania zarówno pozytywne, jak i negatywne. Do osiągnięć zdecydowanie pozytywnych w budowaniu obu typów kapitału społecznego zaliczyć należy wzrost liczby osób ze średnim i wyższym wykształceniem (tab. 2).

Tab. 2. Zmiany poziomu wykształcenia ludności w wieku 15 lat i więcej w Polsce w latach 1970-2011 (w \%)

\begin{tabular}{|c|c|c|c|c|c|c|}
\hline Lp. & Lata & Wyższe & Średnie & $\begin{array}{c}\text { Zasadnicze } \\
\text { zawodowe }\end{array}$ & Podstawowe & Pozostałe \\
\hline 1 & 1970 & 2,7 & 13,4 & 10,6 & 48,8 & 24,5 \\
\hline 2 & 1988 & 6,5 & 24,8 & 23,7 & 38,6 & 6,4 \\
\hline 3 & 1990 & 6,7 & 25,3 & 24,3 & 37,9 & 5,8 \\
\hline 4 & 2002 & 9,9 & 28,3 & 23,2 & 29,8 & 5,6 \\
\hline 5 & 2011 & 17,0 & 29,0 & 21,7 & 18,3 & 6,6 \\
\hline
\end{tabular}

Źródło: opracowanie własne na podstawie GUS 1993, GUS 2012a

Poziom wykształcenia ludności na ogół wpływa pozytywnie na podejmowanie relacji społecznych, inicjatywy i otwartość danych grup. Równocześnie obserwujemy stałe podnoszenie się poziomu wykształcenia nauczycieli. Jednym z jego wskaźników jest stopnień awansu zawodowego, który odzwierciedla posiadaną wiedzę merytoryczną i nabyte kompetencje pedagogiczno-dydaktyczne oraz doświadczenie zawodowe (tab. 3). Na ogół wyższe kompetencje i doświadczenie nauczyciela pozytywnie wpływa na podniesienie jakości pracy szkoły w zakresie realizacji celów kształcenia, a tym samym na efektywność procesu nauczania. To, co budzi niepokój, to stosunkowo niewielki odsetek osób zatrudnionych w szkołach jako nauczyciele stażyści - 4,7\%. Nauczyciele po osiągnięciu statusu nauczyciela mianowanego lub dyplomowanego stają się mniej aktywni w zakresie samokształcenia i uczestnictwa w zorganizowanych formach dokształcania. W przypadku niektórych szkół może to wpływać na tworzenie się grup o cechach kapitału inkluzywnego, zamykającego się na zmiany płynące z zewnątrz (nowe strategie, formy i metody kształcenia, rozwiązania dydaktyczne itp.) Również dla prawidłowych relacji nauczyciel-uczeń nie jest wskazane, aby w szkole dominowali nauczyciele o długim stażu pracy. Obecnie średnia wieku nauczyciela uczącego w polskiej szkole wynosi 40 lat i wykazuje tendencje wzrostowe.

Kolejnym zjawiskiem, które może niepokoić, jest silna koncentracja szkolnictwa ponadgimnazjalnego w miastach wojewódzkich i powiatowych (Czapiewski i in., 2011; Tracz i in., 2001, 2009). Powoduje to ograniczenia w dostępie młodzieży, zwłaszcza szkół podstawowych i gimnazjów, do placówek kulturalno-oświatowych, uczestnictwa w zajęciach pozalekcyjnych ze względów na niedostosowanie komunikacji lokalnej do planu zajęć szkół. 
Tab. 3. Nauczyciele według awansu zawodowego w roku szkolnym 2005/06 i 2011/12 (w\%)

\begin{tabular}{|l|c|c|}
\hline Nauczyciele wg formy awansu zawodowego & $2005 / 06$ & $20011 / 12$ \\
\hline Nauczyciele bez awansu & 1,3 & 1,6 \\
\hline Nauczyciel stażysta & 5,2 & 4,7 \\
\hline Nauczyciel kontraktowy & 15,6 & 18,5 \\
\hline Nauczyciel mianowany & 52,7 & 27,4 \\
\hline Nauczyciel dyplomowany & 25,0 & 46,9 \\
\hline
\end{tabular}

Źródło: opracowano na podstawie: GUS (2006), GUS (2012c)

Trudny do zaakceptowania jest także proces likwidacji szkół. Wśród przyczyn zamykania placówek najczęściej wymienia się: uwarunkowania demograficzne, ekonomiczne oraz reorganizację sieci szkolnej (tab. 4). Niestety, w ostatnich kilku latach istotnym czynnikiem decydującym o istnieniu szkoły są środki finansowe, a nie tylko procesy demograficzne.

Tab. 4. Zmiana liczby szkół i uczniów w Polsce w roku szkolnym 2000/01 i 2011/12

\begin{tabular}{|c|c|c|c|c|}
\hline Wyszczególnienie & \multirow[t]{2}{*}{$2000 / 01$} & \multirow[t]{2}{*}{$2011 / 12$} & \multicolumn{2}{|c|}{$\begin{array}{c}\text { Zmiana } \\
2000 / 01=100 \%\end{array}$} \\
\hline Szkoły & & & Liczba & $\%$ \\
\hline podstawowe & 16766 & 13772 & 2994 & $-17,85$ \\
\hline gimnazja & 6205 & 7331 & 1126 & 18,15 \\
\hline licea ogólnokształcące & 2292 & 2345 & 53 & 2,31 \\
\hline licea profilowane & nie funkcjonowały & 438 & - & - \\
\hline technika & 5724 & 2065 & 3664 & $-64,01$ \\
\hline zasadnicze szkoły zawodowe & 2372 & 1754 & 618 & $-26,05$ \\
\hline Liczba uczniów & \multicolumn{2}{|c|}{ w tys. } & & \\
\hline podstawowe & 3320,6 & 2187,2 & 1033,3 & $-32,08$ \\
\hline gimnazja & 1189,9 & 1210,0 & 20,1 & 1,69 \\
\hline licea ogólnokształcące & 924 & 606,1 & 317,9 & $-34,4$ \\
\hline licea profilowane & nie funkcjonowały & 26,4 & - & - \\
\hline technika & 964 & 528,8 & 438,8 & $-45,16$ \\
\hline zasadnicze szkoły zawodowe & 542 & 210,9 & 331,1 & $-61,09$ \\
\hline
\end{tabular}

Źródło: opracowanie własne na podstawie: GUS (2012b)

Likwidacja szkół wywołuje ostre protesty społeczne, które czasami przeradzają się w ważne inicjatywy lokalnej społeczności, np. prowadzenie społecznej placówki oświatowej. Obecnie funkcjonuje ok. 300 tego rodzaju szkół. Niestety, nie jest to praktyka powszechna. Niekorzystne zjawiska społeczne związane z ograniczaniem dostępu do placówek oświatowych i kulturalnych wykazały badania prowadzone w powiecie proszowickim (woj. małopolskie) przez Zajączkowską (2009). Szkoła na obszarach wiejskich jest często jedyną placówką kulturalną, wokół której skupia się życie lokalnej społeczności. Nieprzemyślane 
decyzje o likwidacji szkół wpływają niekorzystnie na rozwój wzajemnego zaufania w społeczności, a także na nawiązywanie relacji przez uczniów z grupami rówieśniczymi, budowanie zaufania do nowo poznanych grup. Z perspektywy budowania kapitału społecznego są to ważne relacje, które warto kształtować. Rozważanie funkcjonowania szkoły tylko z punktu widzenia ekonomicznego (zysku) nie buduje zaufania mieszkańców do instytucji i władz samorządowych. Samorząd powinien w tych sytuacjach szukać wspólnych rozwiązań ze społecznością lokalną, aby nie dopuścić do zamykania placówek. Niestety z praktyki wynika, iż często brakuje zrozumienia dla racji rodziców i uczniów. Zyski ekonomiczne z zamknięcia szkoły stanowią najczęściej niewielkie oszczędności dla gminy, a zerwane więzi społeczne często trudno odbudować.

Polityka edukacyjna w zakresie rozwoju poziomu kapitału ludzkiego i kapitału społecznego realizowana jest także przez dobór przedmiotów i zajęć edukacyjnych oraz programy wychowawcze. W procesie edukacji zarówno działania wykonywane przez uczniów, jak i wiadomości, które przyswajają, kształtują ich umiejętności oraz postawy. Elementy te tworzą układ o wyraźnej strukturze odpowiadający procesom psychicznym obejmowanych kształceniem, tj.: emocje, poznanie i zachowanie: wiążąc te procesy w system (Niemierko, 2011).

W procesie kształcenia, który sprzyjałby kreowaniu kapitału ludzkiego i kapitału społecznego uczniów, zdaniem B. Niemierko (2011) powinno się kierować uwagę nauczycieli na następujące kwestie:

- Uwzględnianie w ocenie szkolnej (np. opisowej ocenie) nie tylko wiadomości i umiejętności przedmiotowych, ale także pozapoznawczych (emocjonalnych i charakterologicznych) dziedzin rozwoju ucznia, co służy łagodzeniu trudności ucznia z wyobrażeniem o swojej wartości.

Praktyka edukacyjna i badania pokazują, iż wewnątrzszkolne wielokryterialne ocenianie społeczno-wychowawcze dokonywane przez nauczyciela pozwala na równie dobre przewidywanie osiągnięć ucznia w szkole wyższego szczebla, przyszłej pracy zawodowej, jak egzamin zewnętrzny (prowadzony przez Centralną Komisję Egzaminacyjną), który jest zazwyczaj wąsko dydaktyczny i jednokryterialny.

- Niesprowadzanie osiągnięć ucznia tylko do wiadomości i umiejętności przedmiotowych, gdyż poszczególne grupy przedmiotów sprzyjają kształtowaniu różnorodnych kompetencji, zachowań i postaw.

Przedmioty z grupy humanistycznej kształtują i usprawniają komunikację społeczną, wyposażają ucznia w znajomość języków, literatury, historii, stosunków społecznych, kształtują postawy prospołeczne. Przedmioty matematyczno-przyrodnicze natomiast kształtują myślenie teoretyczne i sytuacyjne, poszerzają i pogłębiają znajomość otaczającej rzeczywistości, rozwijają umiejętności pokonywania trudności teoretycznych i praktycznych, kształtują racjonalny światopogląd.

- Uwzględnianie w większym zakresie w nauczaniu przedmiotowym metod pracy grupowej i zespołowej oraz sprawdzanie i ocenianie osiągnięć zespołu uczniowskiego, ponieważ te działania na lekcjach poszczególnych przedmiotów sprzyjają rozwojowi kapitału społecznego przez kształtowanie umiejętności komunikacji w grupie i między uczniami, współdziałania, samokontroli oraz akceptowania różnych zdań, opinii i postaw. 
Istnieje obawa, iż wprowadzona w roku szkolnym 2012/13 podstawa kształcenia ogólnego w szkołach ponadgimnazjalnych polegająca na bardzo wąskim profilowaniu klasy II i III przy równoczesnym ograniczeniu obligatoryjnego kształcenia ogólnego tylko do I klasy ograniczy kształtowanie wymienionych wyżej kompetencji i umiejętności. Podstaw do takiego wnioskowania dostarcza analiza planów nauczania liceum ogólnokształcącego dla wybranych profilii (Dz.U. nr 7 z 2012). W cyklu trzyletniego kształcenia średnio na nauczanie poszczególnych przedmiotów przeznaczono z ogólnej puli godzin: języka polskiego $13,1 \%$, języków obcych $-16,0 \%$, matematyki $-12,0 \%$, przedmiotów społecznych $-6,4 \%$, przedmiotów przyrodniczych - 4,3\%, przedmiotów z wybranego profilu - 34,0\% i uzupełniających do profilu $-4,4 \%$, kultury fizycznej $-9,8 \%$.

Kształcenie specjalistyczne jest ważne, gdyż obserwujemy pogłębiającą się specjalizację w społeczeństwie informacyjnym, a posiadanie rzadkich umiejętności i wiedzy jest niezbędne. Równocześnie jednak potrzebne są osoby z ogólnym wykształceniem, które wąskospecjalistyczne problemy rozważają z innej perspektywy i szukają alternatywnych rozwiązań, formułując idee, programy oraz zasady działania. Koncepcja preferowania wiedzy jednej grupy przedmiotów kosztem innych - np. nauk przyrodniczych, może doprowadzić do jeszcze większego pogłębienia się analfabetyzmu wśród uczniów. Redukcja treści nauczania przy obserwowanym procesie obniżania wymagań (egzaminacyjnych) może znacząco utrudnić przyszłym absolwentom podejmowanie dalszego kształcenia, a w przyszłości utrudni zaspokojenie potrzeb gospodarki kraju.

Promowanie wąskiej praktyczności w nauczaniu uczniów (a także studentów) prowadzi do przekształcenia się szkoły ogólnokształcącej (liceum ogólnokształcące) z placówki formującej przyszłych uczniów (studentów) i elitę naukową oraz obywatelską w szkoły wąskich specjalistów albo wyłącznie wyrafinowanych konsumentów.

Część pedagogów dostrzega w treściach kształcenia w szkole ogólnokształcącej ukierunkowanie na indywidualistyczne podejście do relacji grupowych, społecznych. Pod wpływem idei wolnorynkowych edukacja bardziej sprzyja kształtowaniu, a raczej wyposażaniu jednostek w potrzebne dla pracy w przyszłych korporacjach umiejętności, zachowania i wzorce (np. rywalizacja, kierowanie się własnym interesem, racjonalność ekonomiczna, rozpoznawanie i dążenie do sukcesu), sprzyjając kształtowaniu często zbytniego indywidualizmu zamiast umiejętności współpracy i budowania zaufania do innych osób, grup (Kożyczkowska, 2005; Dudzikowa, 2008). Programy wychowawcze wielu szkół - gimnazjów i szkół ponadgimnazjalnych - nastawione są wyłącznie na rozliczanie punktowe określonych zachowań i działań uczniów w ramach społeczności szkolnej. Takie podejście nie sprzyja budowaniu kapitału społecznego, współpracy, wzajemnego zaufania między uczniem i wychowawcą oraz uczniami a szkołą jako instytucją.

Edukacja w społeczeństwie informacyjnym w wyniku oddziaływania neoliberalnych zasad traktowana jest najczęściej jako rodzaj usługi, a zatem podlega ona takim samym prawom rynku jak każda inna usługa. W tym rozumieniu w działalność placówek oświatowych zostają wpisane nie tylko cele edukacyjne (wychowanie, kształcenie, opieka), ale także cele ekonomiczne (opłacalność i minimalizacja kosztów). Realizowany jest jawny program dotyczący równości szans edukacyjnych i tym samym rozwojowych jednostki i grup, wolności 
działania, otwartości na zmiany i nowe możliwości. Dla jednostki na ogół lepsze wykształcenie wiąże się z poprawą sytuacji materialnej. Równocześnie uwidacznia się ukryty proces polegający na wzmacnianiu uprzedzeń społecznych, podziału na biednych i bogatych, wykorzystywaniu mechanizmu selekcji społecznej (Kożyczkowska, 2005). Proces ten wzmacniają dodatkowo rekrutacje prowadzone do gimnazjów i szkół ponadgimnazjalnych, gdzie tzw. popularne szkoły osiągające wyższe wyniki kształcenia (mierzone najczęściej wynikami egzaminów zewnętrznych, liczbą olimpijczyków) przyciągają zdolnych uczniów, a uczniowie o niższych kompetencjach intelektualnych oraz dzieci osób niepracujących lub ubogich podejmują edukację w mniej renomowanych szkołach. To ścisłe podporządkowanie edukacji rynkowi pracy powoduje niepokojące zjawiska podziału społecznego, na co zwracają uwagę pedagodzy (Kożyczkowska, 2005; Dolata, 2009). Edukacja w koncepcji usługi rynkowej uzyskuje inny wymiar, z jednej strony wyposaża w wiedzę i kompetencje, z drugiej jednak stwarza narzędzie selekcji społecznej.

$\mathrm{Na}$ zakończenie warto odnieść się do nowych form kształtowania relacji społecznych, w tym i budowania kapitału społecznego, jakie oferują współczesne technologie informacyjno-komunikacyjne coraz powszechniej wykorzystywane w procesie kształcenia. Są przygotowywane i wdrażane programy wyposażenia szkół w sprzęt (komputery, dostęp do Internetu, sale komputerowe), a także programy kształcenia, które można wykorzystać w procesie nauczania, komunikowania się nauczycieli z rodzicami (np. dziennik elektroniczny), rozwijania sprawności ich wykorzystania przez uczniów do zdobywaniu informacji i samokształcenia (np. e-lerning). Równocześnie odnotowywane są negatywne skutki związane $\mathrm{z}$ nieprawidłowym oddziaływaniem technologii na postrzeganie rzeczywistości przez uczniów, m.in. zanik umiejętności czytania ze zrozumieniem, tabloidyzacja rzeczywistości, brak ostrożności przy zawieraniu kontaktów w sieci. Jak będzie w przyszłości przebiegać proces kształtowania relacji społecznych w sieci, jest pytaniem otwartym. Szkoła daje tutaj duże możliwości wskazywania poprawnych wzorów działania i postępowania.

\section{Podsumowanie}

Edukacja jest jednym z obszarów, w których rozwijane i kształtowane są kapitał ludzki i kapitał społeczny jako dyspozycje jednostkowe oraz grupowe. Mają one określoną wartość na rynku pracy i dla rozwijającego się społeczeństwa. Wydaje się, iż edukacja w teraźniejszym nastawionym wyłącznie na wynik ekonomiczny świecie, powinna także dążyć do stwarzania szans na kształtowanie postaw zaufania społecznego, odpowiedzialności za podejmowane przez jednostkę lub grupę decyzje i rozwiązania. Temu zadaniu służą odpowiednio przygotowane programy nauczania, programy wychowawcze szkoły, włączanie młodzieży w różnorodne działania na rzecz społeczności lokalnej, nawiązywanie współpracy z instytucjami w realizacji wybranych zadań, by kształtować postawy budowania zaufania i otwartości na zachodzące zmiany. Również w procesie edukacji działania podejmowane w zakresie wyposażania w wiedzę, kształtowania umiejętności i kompetencji oraz wartości 
i postaw powinny przyczyniać się do zmian w świadomości uczących ukierunkowanych na przyszłość.

Wiele zadań stawianych edukacji w zakresie kształtowania kapitału ludzkiego i społecznego wymaga harmonijnego i odpowiedzialnego działania Ministerstwa Edukacji Narodowej w zakresie kreowania polityki edukacyjnej oraz władz samorządów odpowiedzialnych za ich realizację. Praktyka pokazuje jednak, że w tych relacjach obecnych jest wiele negatywnych zjawisk, które ograniczają efektywne działania. Stałe monitorowanie i budowanie narzędzi służących pomiarowi form i poziomu kapitału powinno pomóc w diagnozowaniu stanu i wypracowywaniu najlepszych rozwiązań w celu podnoszenia poziomu zaufania społecznego, więzi społecznych, kreatywności i otwarciu na nowe wyzwania.

\section{Literatura}

Borowiec, M., Dorocki, S., Jenner, B. (2011). Wpływ zasobów kapitału ludzkiego na kształtowanie społeczeństwa informacyjnego. Prace Komisji Geografii Przemystu Polskiego Towarzystwa Geograficznego, 13, 95-109.

Coleman, J. (1990). Foundation of Social Theory. Cambrige: Harvard University Press.

Czapiński, J. Panek, M. (red.) (2011). Diagnoza społeczna 2011. Warunki i jakość życia Polsków. Raport. Warszawa: Rada Monitoringu Społecznego.

Czapniewski, K. Janc, K. (2012). Rola wiedzy na wsi - edukacja a praca. W: W. Kamińska, K. Helfer (red.), Wiejskie rynki pracy - zasoby aktywizacja, nowe struktury. Warszawa: KPZK PAN, 278301.

Dolata, R. (2009). Cicha rewolucja w polskiej oświacie - proces różnicowania się gimazjów w dużych miastach. W: B. Niemierko, K. Szmigel (red.), Badania międzynarodowe i wzory zagraniczne $w$ diagnostyce edukacyjnej. Kielce: PTDE, 111-123.

Dudzikowa, M. (2008). Erozja kapitału społecznego w szkole w kulturze nieufności. W: M. Dudzikowa, M. Czerepaniak-Walczak (red.), Wychowanie. Pojęcia, procesy, konteksty: interdyscyplinarne ujęcie. T. 4. Gdańsk: Gdańskie Wydawnictwo Psychologiczne.

Dziennik Urzędowy MEN nr 7. (2012).Warszawa: Ministerstwo Edukacji Narodowej.

Fukuyama, F. (2003). Kapitał społeczny. W: L.E Harrison, S.P. Huntington (red.), Kultura ma znaczenie. Poznań: Zyski S-ka.

GUS (1993). Rocznik statystyczny - demografia. Warszawa.

GUS (2006). Oświata i wychowanie w roku szkolnym 2005/06. Warszawa.

GUS (2012). Oświata i wychowanie w roku szkolnym 2011/12. Warszawa.

GUS (2012a). Rocznik demograficzny. Warszawa.

GUS (2012b). Rocznik statystyczny. Warszawa.

Juszczyk, K. (2007). Edukacja, wiedza i umiejętności jednostki w zmieniającym się świecie. Chowanna, $29,(2), 16-36$.

Kamińska, W. Helfer, K. (red.), 2012, Wiejskie rynki pracy - zasoby, aktywizacja, nowe struktury. Warszawa: KPZK PAN.

Kastro, K. (2005). Kapitał społeczny w teorii ekonomicznej. Gospodarka Narodowa, 7-8.

Kożyczkowska, A. (2005). Problem pracy i braku pracy w kontekście zmiany rynku pracy. Konstatacja pedagoga. Kwartalnik Pedagogiczny, 4, 167-185. 
Kwiatkowski, M. (2005). Kapitał społeczny. W: H. Kubiak (red.), Encyklopedia socjologii. Warszawa: Oficyna Naukowa

Niemierko, B. (2011). Jak mierzyć kapitał ludzki i kapitał społeczny? Edukacyjne perspektywy operacjonalizacji pojęć ekonomicznych. Zeszyty Naukowe Akademii Marynarki Wojennej, 52, (4), 257-275.

Polska 2030 - Trzecia fala nowoczesności. Dlugookresowa Strategia Rozwoju kraju. (2012). Warszawa: Ministerstwo Administracji i Cyfryzacji.

Putnam, R.D. (1995). Demokracja w działaniu. Tradycje obywatelskie we wspótczesnych Włoszech. Wydawnictwo Znak: Warszawa-Kraków.

Sierocińska, K. (2011). Kapitał społeczny, definiowanie, pomiar i typy. Studia Ekonomiczne (Economic Studies), 68, (1).

Tracz, M. Mróz, G. (2001). Szkolnictwo w województwie małopolskim. Folia Geographica Oeconomica, 30-31, 207-222.

Tracz, M. Borowiec, M. Mróz, G. (2009). Szkolnictwo w województwie podkarpackim. Folia Geographica Oeconomica, 32, 223-234 .

Węziak-Białowolska, D. (2010). Kapitał społeczny w Polsce - propozycje pomiaru i wyniki. Zeszyty Naukowe Instytutu Statystyki i Demografii SGH, 4, 1-28.

Wiktorzak, A. (2009). Kapitał społeczny szkoły. W: B. Niemierko, M.K. Szmigel (red.), Badania zagraniczne i wzory międzynarodowe w diagnostyce edukacyjnej. Kraków: PTDE, 95-108.

Woolcock, M. (1998). The Place of Social Capital In Understanding Social and Economic Outcomes. Pozyskano z http:/ocecd.org.dataoeced/5/13.1824913pdf

Zajączkowska, J. (2009). Przemiany szkolnictwa w powiecie proszowickim pod wptywem transformacji spoteczno-ekonomicznej Polski (maszynopis).

Zioło, Z. (2009). Rola przemysłu w procesie kształtowania społeczeństwa informacyjnego. Prace Komisji Geografii Przemystu Polskiego Towarzystwa Geograficznego, 13, 95-109.

Mariola Tracz, dr, Uniwersytet Pedagogiczny w Krakowie, Instytut Geografii, Zakład Dydaktyki Geografii.

Geograf, dydaktyk geografii, zainteresowania badawcze: funkcja edukacji w społeczeństwie, historia nauczania i dydaktyki geografii, cele, treści i osiągnięcia w nauczaniu geografii, przyrody oraz podstaw przedsiębiorczości.

Mariola Tracz, PhD, geographer, geography teacher. Research interest: the function of education in society, the history of teaching and learning geography and geographical education, the aim, content and assessment in teaching and learning geography, science and introduction to business.

adres/address: Uniwersytet Pedagogiczny w Krakowie,

Instytut Geografii, Zakład Dydaktyki Geografii, ul. Podchorążych 2, 30-084 Kraków, Polska

e-mail:mtracz@up.krakow.pl 